\title{
Sociology and American Studies: A Case Study in the Limits of Interdisciplinarity
}

\author{
Joshua Kjerulf Dubrow
}

Published online: 8 April 2011

(C) The Author(s) 2011. This article is published with open access at Springerlink.com

\begin{abstract}
American Studies is an academic discipline whose object of study is the United States of America and everything associated with it, and American sociologists largely ignore it. American Studies largely ignores American sociology. What causes this mutual exclusion? An outline of the disciplinary history of American Studies and journal article citation data show that the relationship between sociology and American Studies is weak and asymmetrical; American Studies cites sociology more often, but very little and not by much. I argue that mutual exclusion is due to mutual distrust in methods: sociology sees itself as a science, while American Studies, with roots in history and literature, does not. This article serves as a case study in the limits of interdisciplinarity.
\end{abstract}

Keywords American Studies · Sociology · Interdisciplinarity · Multidisciplinarity · Citation counts

American Studies is an academic discipline whose object of study is the United States of America and everything associated with it, and sociology, including American sociology, largely ignores it. American Studies largely ignores sociology. What causes this mutual exclusion? This article should be of interest to sociologists who study America for two reasons. First, American Studies produces knowledge that sociologists who study the U.S. might want to use. Second, this is the rare, indepth case study that shows how disciplines can simultaneously share interests and exclude each other from their most visible research outlets (Jacobs and Frickel 2009). Mutual exclusion has consequences for the means and ends of academic knowledge (Abbott 2001). Interdisciplinarity has its limits, and the story of sociology and American Studies shows how potential interdisciplinary relationships fail.

J. K. Dubrow ( $\bowtie)$

Institute of Philosophy and Sociology, Polish Academy of Sciences,

72 Nowy Swiat, 00-330 Warsaw, Poland

e-mail: dubrow.2@osu.edu 
This article is intended for a sociology audience; as such I start by outlining the history and intellectual trends of American Studies. A similar outline for sociology can be found elsewhere (Williams and MacLean 2005; see also Platt 2007). Next, I provide evidence of the mutual exclusion using ISI Citation data based on the top journals in American Studies and sociology. I then pose four possible explanations of the mutual exclusion, and end with a discussion of its consequences for interdisciplinarity.

\section{What is American Studies?}

It is safe to say that most sociologists, even American sociologists, have not thought enough of American Studies as a discipline to investigate its history and intellectual trends. I begin with a short history of American Studies to orient the sociologist to the discipline. Theoretically, anything with America as its subject could be classified as "American Studies." To restrict the article's scope, I focus on American Studies as a formal academic discipline, rather than an enterprise taken up by anyone with a voice (written or otherwise) and an interest in America.

Historians of American Studies refer to the discipline as a "movement" (Wise 1979; see also "Special Section: The American Studies Movement: A Thirty-Year Retrospective" in American Quarterly 1979, vol. 31). Leo Marx (1979), one of American Studies' founders, saw the goals of the American Studies movement as a "convenient means to circumventing the [conservative] bias" of the "tradition-bound History and English departments" (398). Pease and Wiegman (2002) argue that the word "movement" is used because it "defines [American Studies] explicitly as a knowledge project more expansive than the academic field" (5). Within this "liberation" narrative, the American Studies movement freed scholars to pursue a broadly interdisciplinary project devoted to the study of America in all its aspects. Marx (1979) claims that American Studies' goal is the mass incorporation of women and ethnic minorities - both their history and as academics - into a progressive, inclusive, and liberated academic profession.

Another, not-necessarily-competing narrative sees American Studies as a child of World War Two and its aftermath, professionalized in a time of hot nationalist fervor (Gleason 1984; Davis 1990). Although attempts at organizing American Studies as a discipline began in the 1920s, and continued with degree programs in American Civilization at Harvard and Yale in the 1930s, the primary disciplinary apparatus was formally constructed in the aftermath of the war: The 1940s accelerated the number of universities offering American Studies degrees; its main journal, American Quarterly, was founded in 1949, and the American Studies Association in 1951 (Wise 1979). American Studies grew in a Cold War environment where the Central Intelligence Agency and other organs of the federal government aggressively sought American hegemony in cultural and educational production in America and abroad as a weapon in the fight against communism (Wise 1979; Gleason 1984; Davis 1990: 354-356; Berube 2003; see also Judt 2005: Chapter 5). American philanthropies such as the Carnegie Corporation poured large amounts of money into American Studies programs; by 1947 over 60 places of higher learning offered majors in American Studies (Wise 1979). Eventually, the discipline became 
embedded in enough major universities that philanthropy just to keep American Studies departments alive was no longer the norm. ${ }^{1}$ That the State intervenes in academic affairs is, by now, axiomatic, and speculation about American Studies' ideological origins is a cottage industry. ${ }^{2}$

The construction of American Studies in Europe has a similar history (Skard 1958). Europe after World War Two saw an uptick in interest in American culture, spurred by the Europeans themselves and by the Americans who flooded the wardevastated European economic, educational and cultural market. American Studies programs in Western Europe and Scandinavia were established in the late 1940s. In the 1950s, due to the European economic boom, construction of the disciplinary infrastructure accelerated. This infrastructure was laid with the help of American economic aid, but by the time of the Fulbright-Hays Act of 1961, institutes of American Studies in European universities became increasingly independent and self-sufficient (Skard 1958: 39-41). Not all Europeans embraced American Studies; many were skeptical of America's involvement in European education after the war and questioned their motives. While seeking "common cultural foundations of the West" (Skard 1958: 39), Europeans were very much aware that America had deep flaws in its society. To this day, American Studies in Europe is strong, with leading journals such as Amerikastudien and Revue Française d'études Américaines.

American Studies was not confined to the West: the Union of Soviet Socialist Republics, Yugolsavia, and the countries of Central and Eastern Europe also had American Studies programs (emerging, of course, without Western aid). Soviet versions of American Studies began very soon after the 1917 revolutions, around the time Lenin declared a bipolar world with socialist countries on one side and capitalist ones on the other. Writing of the mid-20th Century Soviet version of American Studies, Skard (1958) argued that, "In the Soviet Union and in all the satellite territories a propagandistic study of America became an important part of the formation of public opinion..." (39). Soviet studies of America also influenced their domestic and foreign policy (Brown 2009). From 1945 to 1971, over 700 books were published in the Soviet Union on "American problems," half on foreign policy and diplomacy; in 1971 alone there were 50 books and hundreds of other works published on American history and economics (Bolkhovitinov 1975). After 1989, American Studies were refashioned in many Eastern European countries. For example, the American Studies Center of the University of Warsaw was officially created in 1976 as a small research center. In 1992, with substantial funds from the United States Embassy in Warsaw, they moved to a new building with much more space, instituted an M.A. degree in American Studies and built the largest American Studies library in Central Europe. ${ }^{3}$

Like sociology, the definition of American Studies and its main intellectual currents are contested terrain. Insomuch as it can be defined, American Studies is

\footnotetext{
${ }^{1}$ Governmental sponsorship of American studies did not end in the 1950s; for example, in 1971, the National Endowment for the Humanities funded an organization to promote American Studies in community colleges, high schools and museums.

${ }^{2}$ For state intervention into the social sciences, see Oppenheim (1969) on Project Camelot.

3 Today, staff members at the American Studies Center (ASC) say that the U.S. Embassy in Warsaw has not donated money to the ASC in many, many years. Yet, on occasion the U.S. Embassy requests the use of the technologically advanced classrooms there, and can do so on short-notice.
} 
an academic discipline and interdisciplinary endeavor that bridges history, literature, American philosophy and the social sciences, among others, whose object of study is everything related to the United States of America. Others define it simply as "the study of American culture, past and present, as a whole" (Smith 1959: 197). From the beginning until now, from the U.S. to Europe, the academic disciplines of history and American literature dominate American Studies research and training.

As with all disciplines, American Studies' intellectual paradigms shift over time. At its inception in both the United States and Europe, the focus was on Americans' national character. This was a long figuring-out of how Americans think-the idealized "American mind"-bolstered by the idea of American exceptionalism; classics in this vein include Henry Nash Smith's Virgin Land (1950) and R. W. B. Lewis' The American Adam (1955). Beginning in the 1960's, a growing number of American Studies scholars criticized their disciplinary founders as creating "an overly timid and elitist white Protestant male enterprise which tended to reinforce the dominant culture rather than critically analyzing it" (Wise 1979: 312). Strong internal criticism splintered American Studies. Social movements organized against the ills of racism, sexism, and sexual repression gave rise to revolutionary academic disciplines of African American Studies, Gender Studies and Gay and Lesbian Studies. From the 1990s on, more and more American Studies scholars became increasingly concerned with America's role as the lone superpower. A comparativist subfield explicitly compared the U.S. with other countries. Others took names such as post-hegemonic and counter-hegemonic, indicating a U-turn from founders' focus on American exceptionalism (Pease and Wiegman 2002).

In this short outline of American Studies, sociology plays a marginal role. In terms of training and research, American Studies is strong on history and literature and only tentatively connected to the social sciences. In a typical American Studies reader, readings come from literary critics and history's celebrities (public speeches by U.S. presidents, famous dissidents, and cultural icons), and the only overt sociology link is the odd article by Max Weber, most likely from the Protestant Ethic and the Spirit of Capitalism (e.g. Horwitz 2001). When the social sciences are invoked, it is usually in discussions of methodology and empirical research. In keeping with the "American Studies as social movement" motif, others argue for a greater role for the social sciences because its empiricism can provide evidence for claims made in support of politically progressive ideas (Lauter 2002).

Sociology's marginalization in American Studies is a cross-national phenomenon which the trend toward comparative research changed little (for a history of American Studies internationalization, see Hornung 2005). The recent focus on internationalizing American Studies-actively recruiting scholars from countries outside the United States into U.S. based professional meetings of American Studies scholars and generating research that is more explicitly comparative (Emory 2007) is not about shifting the focus from history and literature to sociology. The 2004 President of the American Studies Association wondered, "What topics and questions become salient if we reconceived our field with the transnational at its center? What roles might comparative, collaborative, border-crossing research play in this reconfigured field?" (Fishkin 2005: 21-22). Conversely, there are no serious 
discussions within sociology about actively recruiting American Studies scholars into sociology meetings.

\section{Measuring the Relationship}

I conceptualize the relationship between American Studies and sociology as the extent to which they cite each other in their most influential journals. I measure this concept with citations of full-length articles and presidential addresses contained in the main journals of each discipline. Data on article citations come from the ISI Web of Science Citation Database.

The list of American Studies journals come from the website of American Studies' main professional association, the American Studies Association. From their list, I examine only those journals that were also listed in the ISI Citation Database $(N=10)$. In alphabetical order they are: African American Review, American Quarterly, American Studies in Scandinavia, Journal of American History, Journal of American Studies, Canadian Review of American Studies, Amerikastudien/American Studies, AAA-Arbeiten aus Anglistik und Amerikanistik, Revue Française d'études Américaines, and the Journal of American Culture.

To compare, I selected the top 15 sociology journals. This includes the top 14 journals by 5-year average impact factor. In order of their impact factor, they are: Annual Review of Sociology, American Journal of Sociology, American Sociological Review, Journal of Marriage and the Family, Sociology of Education, Social Problems, Sociology of Health \& Illness, Social Networks, Sociological Methods \& Research, Economy \& Society, British Journal of Sociology, Population \& Development Review, Social Forces, and Sociologia Ruralis. Some may argue that the choice of journals introduces selection bias in that these sociology journals are too oriented toward sociology, and are not interdisciplinary. I assume that the degree of interdisciplinarity of a journal's focus influences the extent to which articles in that journal cite articles from journals of other academic disciplines. To account for this, I also include Gender \& Society (impact factor of 1.34, and currently the second highest ranked journal in Women's Studies), which is more interdisciplinary in terms of the academic disciplines of history and literature than the mainstream sociology journals above and should be more likely to cite an American Studies journal article. Unless otherwise noted, the time frame for citations is 1965-2009. The point of my analysis is to show extent of cross-citations between American Studies and sociology journals; considering how small the absolute numbers are, weighting by journals' founding date is unnecessary.

\section{Results}

In absolute terms, it is a rare event when any sociology journal article cites an American Studies journal article. To illustrate absolute rarity, I first contrast the top three American Studies journals with two journals from disciplines that sociology historically has had strong ties: political science (American Political Science Review) and economics (American Economic Review) (Table 1). The numbers are total article 
Table 1 Comparison of cites in all sociology journals: american studies, political science and economics

Journals

American Quarterly

Journal of American Studies

African American Review

American Journal of Political Science

American Economic Review

ISI Web of Science Citation Database

citations by all sociology journals in the ISI database (not just the top journals). Between 1965 and 2009 sociology journals articles cited American Quarterly articles 174 times, whereas the analogous number for American Economic Review is 2425. Clearly, in contrast with the main journals of political science and economics, American Studies journals are rarely cited. In absolute terms, American Studies' contribution to sociology research outlets is small.

Tables 2 and 3 show how each discipline cites and is cited by the other (for a similar method, see Oromaner 2008); they tell a story of mutual exclusion with two main findings. First, the relationship between sociology and American Studies is weak: these disciplines rarely cite each other. In over 40 years of co-existence measured by these data, the total number of times a major sociology journal cited an article in an American Studies journal is 81. Half of those citations is of articles in American Quarterly (41 cites). Second, the relationship is asymmetric. American Studies cites sociology (205 total cites) almost three times more than sociology cites American studies (81 total cites). The leading citer of American Studies is the American Journal of Sociology, which cited an American Studies journal a mere 17 times in 43 years.

If sociology is not citing American Studies, who is? Between 1965 and 2009, the journals that cite American Quarterly are from history (33\%), humanities/multidisciplinary $(13 \%)$, and literature (American or otherwise) $(19 \%)$, while history of social sciences $(5 \%)$ and sociology $(5 \%)$ are in the middle of the pack. American Sociological Review provides an interesting contrast: this main journal in sociology is cited by sociology (31\%), management ( $9 \%)$, social psychology (6\%), business $(6 \%)$, and political science (5\%): Humanities/multidisciplinary is close to last $(0.32 \%)$.

\section{Explaining the Relationship}

There are four related characteristics of disciplines that explain the weak and asymmetrical relationship between sociology and American Studies.

\section{Objects of Study}

I assume that substantive similarity in the objects of study is a prerequisite for a strong disciplinary relationship, and the first characteristic I examine is whether the disciplines share objects of study. 
Table 2 Number of article citations: how american studies journals cite and are cited by the top sociology journals, 1965-2009

\begin{tabular}{lll}
\hline Name of American Studies Journal & $\begin{array}{l}\text { Cites the Top Sociology } \\
\text { Journals }\end{array}$ & $\begin{array}{l}\text { Is Cited by a Top Sociology } \\
\text { Journal }\end{array}$ \\
\hline African American Review & 0 & 7 \\
American Quarterly & 54 & 41 \\
American Studies in Scandinavia & 6 & 0 \\
Journal of American History & 72 & 17 \\
Journal of American Studies & 8 & 5 \\
Canadian Review of American Studies & 14 & 2 \\
Amerikastudien/American Studies & 5 & 1 \\
AAA - Arbeiten aus Anglistik und & 1 & 0 \\
$\quad$ Amerikanistik & 16 & 0 \\
Revue Française d'études Américaines & 29 & 8 \\
Journal of American Culture & 205 & 81 \\
Total & & \\
\hline
\end{tabular}

ISI Web of Science Citation Database

Journal of American History is 1996-2009

Both sociology and American Studies cover a potentially wide intellectual terrain, but at their core the potential for cross-pollination is great. American Studies are largely concerned with aspects of American society, including its history, culture, and politics. Sociology's objects of study are similar, though discipline-wide they are not limited to the U.S. Both disciplines are concerned with core features of human social life, including race, ethnicity, gender, and social class.

Although the objects of study for both sociologists and American Studies scholars are similar, they remain little aware of each others' work. American sociologists are, by and large, preoccupied with matters of their own country (Smelser 2003); although their myopic research interests should lead them down the tunnel to the similarly myopic American Studies, this rarely happens.

\section{Methods of Inquiry}

Similarity in methodological preferences also contribute to how one discipline influences another, where the more similar the methods, the more likely the interdisciplinary relationship will grow.

Many American Studies scholars argue that the social sciences, in their explanations of the social world, do not adequately account for art, literature and other cultural artifacts. In a famous article on American Studies' search for method, Henry Nash Smith (1959), a founder of American Studies, criticized "recent" directions in literary criticism for not accounting for social context. Turning to sociology, Smith writes, "We are no better off if we turn to the social sciences for help in seeing the culture as a whole. We merely find society without art instead of art without society" (203). He goes on to criticize social science methods such as content analysis and quantification. Nash's fellow founder Leo Marx (1979) 
Table 3 Number of article citations: how the top sociology journals cite and are cited by american studies journals, 1965-2009

\begin{tabular}{|c|c|c|}
\hline Name of Top Sociology Journal & $\begin{array}{l}\text { Cites an American Studies } \\
\text { Journal }\end{array}$ & $\begin{array}{l}\text { Is Cited by an American Studies } \\
\text { Journal }\end{array}$ \\
\hline Annual Review of Sociology & 13 & 12 \\
\hline American Journal of Sociology & 17 & 53 \\
\hline American Sociological Review & 15 & 60 \\
\hline $\begin{array}{l}\text { Journal of Marriage and the } \\
\text { Family }\end{array}$ & 5 & 20 \\
\hline Sociology of Education & 3 & 1 \\
\hline Social Problems & 10 & 25 \\
\hline Sociology of Health \& Illness & 0 & 0 \\
\hline Social Networks & 2 & 0 \\
\hline $\begin{array}{l}\text { Sociological Methods \& } \\
\text { Research }\end{array}$ & 0 & 0 \\
\hline Economy \& Society & 0 & 2 \\
\hline British Journal of Sociology & 0 & 5 \\
\hline $\begin{array}{l}\text { Population \& Development } \\
\text { Review }\end{array}$ & 0 & 4 \\
\hline Social Forces & 8 & 19 \\
\hline Sociologia Ruralis & 1 & 0 \\
\hline Gender \& Society & 7 & 4 \\
\hline Total & 81 & 205 \\
\hline
\end{tabular}

ISI Web of Science Citation Database

American Journal of Sociology is 1965-2008

lamented that a turn toward social science is more regress than progress, a stumbling block on the way to scholarly understanding: "In many universities the amorphous progressivism of the founding generation in American Studies gave way to a kind of social scientistic (sic) positivism, the belief that our subject matter consists of objective data, preferably quantifiable..." (401). Later on, American Studies scholars re-evaluated their founders' position on the matter, but it did not lead to major changes. Beginning in the 1970s, American Studies scholars, particularly from the University of Pennsylvania, sought a more social scientific approach (Wise 1979). Debate over the usefulness of the social sciences for studying American culture has a long, uninterrupted history (see Attebery 1996).

Preferring the "right" methods of inquiry is often seen as a means for achieving legitimacy in the pantheon of academia, but it also becomes a dividing line between disciplines that embrace one kind and shun another. The search for a unique American Studies method is linked to its search for legitimacy as a discipline (Jones 1979). In the end, Nash (1959) argues that American Studies will have to develop its own method, though his latter-day colleagues lament the very thought (Jones 1979; Davis 1990). The "methodology is legitimacy" narrative has parallels in sociology. Mainstream sociological journals reflect the disciplines' striving for legitimacy as a 
science, complete with rigorous application of advanced statistical methods and a decisive bias toward articles that quantify human social life.

Citation counts reflect this mistrust of social science methods. American Studies do not cite, and is not cited by, the main methodologically oriented journals in sociology. For example, there is no citation relationship between American Studies and the journals Sociological Methods and Research and Sociological Methodology. No article in American Studies journals listed here cited Social Networks.

\section{Interdisciplinarity}

To further explain why the relationship between sociology and American Studies is weak, I turn to the literature on interdisciplinarity. Interdisciplinarity is the "communication and collaboration across academic disciplines," where some disciplines "communicate" more than others (Jacobs and Frickel 2009: 44). The most interdisciplinary-focused disciplines often draw knowledge from scholars outside of their own. Highly interdisciplinary-focused disciplines are not dominated by any one discipline; their relationships with all disciplines should be weak.

From the very beginning, American Studies has been an interdisciplinary endeavor. Smith (1959) argued in American Quarterly that "the defining characteristic of American Studies is not the size of its problems but the effort to view any given subject of investigation from new perspectives, to take into account as many aspects of it as possible" (197). A recent president of the American Studies Association reaffirmed the commitment to interdisciplinarity: "American Studies might be defined by this pithy phrase: 'it's not what we choose to include, but what we refuse to exclude" (Deloria 2009: 2).

This conscious interdisciplinarity is also affirmed by American Studies' main professional association, the American Studies Association. ${ }^{4}$ On their website, the American Studies Association lists their disciplinary influences: "Together these members represent many fields of inquiry, such as history, literature, religion, art and architecture, philosophy, music, science, folklore, ethnic studies, anthropology, material culture, museum studies, sociology, government, communications, education, library science, gender studies, popular culture, and others." Note that there is no attempt at alphabetizing. If we see this as a ranked list, sociology is $13^{\text {th }}$, just after museum studies, but closer to library science $\left(17^{\text {th }}\right)$ than history $\left(1^{\text {st }}\right)$ or literature $\left(2^{\text {nd }}\right)$.

By contrast, sociology is much more self-referential without any conscious desire to be interdisciplinary. The American Sociological Association makes no specific claim to interdisciplinarity or the sources of its disciplinary input. According to their mission statement, the American Sociological Association is "dedicated to advancing sociology as a scientific discipline and profession serving the public good." The interdisciplinary Gender \& Society has only cited an American Studies journal 7 times.

\footnotetext{
${ }^{4}$ American Studies Association members engage "American culture from many directions but have in common the desire to view America as a whole rather than from the perspective of a single discipline."
} 


\section{Size}

Differences in discipline size help to explain asymmetry in citations. I assume that between two disciplines with similar objects of study, the larger has greater influence on the smaller one than vice versa. I measure size of the discipline in terms of number of memberships in professional organizations and degree-granting programs. Size is, of course, related to age of the discipline, and sociology is obviously much older than American Studies.

By any measure, sociology is larger than American Studies. In terms of membership of its professional associations, the American Sociological Association has almost three times as many members as the American Studies Association (14,000 to 5,000). Sociology and American Studies both have international professional associations. ${ }^{5}$ The International Sociological Association (ISA, est. 1949) is older than the International American Studies Association to (IASA, established in 2000), and has almost three times as many different countries of membership (109 to "more than 40") than the IASA. Sociology also has the edge in degree-granting programs. According to the National Center for Education Statistics, as of 2009 there were 237 places of higher education that offer AA, BA or advanced degrees in American/United States studies/Civilization. Using the same database, as of 2009 there were 1,126 places of higher education that offer AA, BA or advanced degrees in sociology. ${ }^{6}$

\section{Conclusion and Discussion}

This article can be read on a few levels. On the surface, it is an interesting intellectual puzzle, where two disciplines with very similar objects of study exclude each other from their most visible research outlets. Over the last half century, sociology has been relatively uninformed by American Studies, and although American Studies is somewhat more informed by sociology than vice versa, the difference is slight.

On another level, this is a case study in the limits of interdisciplinarity. By many measures, interdisciplinarity is increasingly popular and a frequent topic of debate: "Among sociologists, interdisciplinarity is lauded as an ideal, scorned as a threat, and embraced as a practice" (Jacobs and Frickel 2009: 44). Federal agencies, private foundations and universities collectively spend billions of dollars to promote interdisciplinarity (Jacobs and Frickel 2009). In a recent review of the state of interdisciplinarity in sociology, the authors conclude that due to lack of research into how disciplinary and interdisciplinary relationships develop, we know little as to whether interdisciplinarity is worth the attention it receives (Jacobs and Frickel 2009).

\footnotetext{
5 There are no available membership figures for the International Sociological Association.

${ }^{6} \mathrm{http}: / /$ nces.ed.gov/collegenavigator/. In terms of departments: in 1992, there were 242 American studies programs http://www.theasa.net/resources/dissertations/the_structure_and_administration_of_american_ studies_programs/
} 
The story of the relationship between sociology and American Studies reveals the high barriers to interdisciplinarity, which consist of "incompatible styles of thought, research traditions, techniques, and languages that are difficult to translate across disciplinary domains" (Jacobs and Frickel 2009: 47). While sociology considers itself a science, American Studies makes no such claim. American Studies embraces what Tate (1973) referred to as a "holistic approach," a systematic synthesis of literature gleaned from all disciplines. The holistic approach is not science as sociologists understand it.

In this case, I attribute most of the problem to a mutual mistrust of each other's methodology. This method gap has severe consequences for the relationship between sociology and American Studies, where disciplinary norms of what constitutes the proper way to apprehend social reality fuel the mutual exclusion (see also Oromaner 2008 and Vanderstraeten 2010). To the American Studies scholar, with no love of numbers and little training in statistics, journals such as American Sociological Review are incomprehensible, and henceforth disregarded. Because sociology views American Studies' research as unscientific, sociology largely ignores it. Sociology's bias toward scientifically and preferably quantifiably derived knowledge works against the use of "unscientific" American Studies journals. This is a two-way-street, and it is exactly sociology's bias which sets American Studies both apart from the social sciences and at a distance from mainstream substantive and methodology oriented sociology journals.

A similar process of mutual exclusion could also characterize the relationship between sociology - and the social sciences generally — and area studies (see Bates 1997). While a full account of this relationship is beyond this article, some similarities are worth noting. Like American Studies, area studies in the U.S. proliferated during the Cold War as a means to marshal the humanities and the social sciences in the global fight against Communism (Katzenstein 2001: 789). As with American Studies, area studies tend to be interdisciplinary in their intellectual focus on particularities of their preferred world region (Ahram 2011). There is a key difference: whereas area studies balk at both general theory building a la political science and generalizing outside their regional focus, I do not see American Studies as overtly against these endeavors.

Despite high barriers to interdisciplinarity, this article can raise awareness among American sociologists of the existence and utility of American Studies. American Studies' potentially greatest contribution to American sociology is in its unique strength, namely the re-interpretation of American history via interdisciplinary research. Indeed, the main sociology journals often use American Studies articles for their historical observations. For example, Welter's (1966) classic article on 19th Century gender relations in America, "The Cult of True Womanhood: 1820-1860," has been cited 552 times (by far the most cited article in American Quarterly's recorded history), 25 of which are in sociology journals, and 16 of those are in the top sociology journals included in this article. Another major contribution of American Studies is that it addresses subjects mainstream sociology pays little attention to. An example is the sociology of humor, where Shifman and Katz's (2005) American Sociological Review article, ""Just Call Me Adonai": A Case Study of Ethnic Humor and Immigrant Assimilation," drew on various sources dealing with ethnicity and humor, including two articles from American Quarterly and one from Journal of American History. 
American Studies scholars are producing knowledge that sociologists can, and have, used. At the same time, American Studies should be more aware that sociological methods are not all quantitative. To ignore sociology's rich tradition of qualitative research is to ignore some of the best knowledge that sociology produces. Perhaps in the next half century, the relationship between sociology and American Studies can turn from mutual exclusion to mutual respect.

Acknowledgments I gratefully acknowledge William Form, Kazimierz M. Slomczynski, Tadeusz Krauze, Irina Tomescu-Dubrow, and Tomasz Basiuk for their helpful comments and suggestions. A version of this paper was presented at the International Institute of Sociology World Congress in 2009 in Yerevan, Armenia, and at my M.A. Thesis seminar at the American Studies Center of the University of Warsaw. I thank the attendees of that session and my students for their comments and suggestions.

Open Access This article is distributed under the terms of the Creative Commons Attribution Noncommercial License which permits any noncommercial use, distribution, and reproduction in any medium, provided the original author(s) and source are credited.

\section{References}

Abbott, A. (2001). Chaos of disciplines. Chicago: University of Chicago Press.

Ahram, A. I. (2011). The theory and method of comparative area studies. Qualitative Research, 11(1), 69-90.

Attebery, B. (1996). American studies: a not so unscientific method. American Quarterly, 48(2), 316-343.

Bates, R. H. (1997). Area studies and the discipline: a useful controversy? PS: Political Science and Politics, 30(2), 166-169.

Berube, M. (2003). American studies without exceptions. PMLA, 118(1), 103-113.

Bolkhovitinov, N. N. (1975). On the present state of american studies in the soviet union. In R. H. Walker (Ed.), American studies abroad (pp. 101-108). Westport: Greenwood Press.

Brown, A. (2009). The Rise and Fall of Communism. New York: Ecco.

Davis, A. F. (1990). Politics of american studies. American Quarterly, 42(3), 353-374.

Deloria, P. J. (2009). Broadway and main: crossroads, ghost roads, and paths to an american studies future. American Quarterly, 61(1), 1-25.

Emory, E. (2007). Diversity in the United States and abroad: what does it mean when american studies is transnational? American Quarterly, 59(1), 1-22.

Fishkin, S. F. (2005). Crossroads of cultures: the transnational turn in american studies. American Quarterly, 57(1), 17-57.

Gleason, P. (1984). World war II and the development of american studies. American Quarterly, 36(3), $343-358$.

Hornung, A. (2005). Transnational American studies: response to the presidential address. American Quarterly, 57(1), 67-73.

Horwitz, R. P. (Ed.). (2001). American Studies Anthology. Wilmington: Scholarly Resources.

Jacobs, J. A., \& Frickel, S. (2009). Interdisciplinarity: a critical assessment. Annual Review of Sociology, 35, 43-65.

Jones, J. M. (1979). American studies: the myth of methodology. American Quarterly, 31(3), 382-387.

Judt, T. (2005). Postwar: A History of Europe since 1945. New York: Penguin Press.

Katzenstein, P. J. (2001). Area and regional studies in the United States. PS: Political Science and Politics, 34(4), 789-791.

Lauter, P. (2002). American studies, american politics and the reinvention of class. In D. E. Pease \& R. Wiegman (Eds.), Futures of american studies (pp. 486-509). Durham: Duke University Press.

Marx, L. (1979). Thoughts on the origin and character of the american studies movement. American Quarterly, 31(3), 398-401.

Oppenheim, A. N. (1969). Knowledge for what? The camelot legacy. The British Journal of Sociology, 20 (3), 326-337. 
Oromaner, M. (2008). Intellectual integration and articles in core sociology journals, 1960-2000. American Sociologist, 39, 279-289.

Pease, D. E., \& Wiegman, R. (Eds.). (2002). Futures of american studies. Durham: Duke University Press.

Platt, J. (2007). Some issues in comparative, macro and international work in the history of sociology. American Sociologist, 38(4), 352-262.

Shifman, L., \& Katz, E. (2005). Just call me Adonai:' A case study of ethnic humor and immigrant assimilation. American Sociological Review, 70(5), 843-859.

Skard, S. (1958). American studies in Europe: Their history and present organization, volumes I and II. Philadelphia: University of Pennsylvania Press.

Smelser, N. (2003). On comparative analysis, interdisciplinarity and internationalization in sociology. International Sociology, 184(4), 643-657.

Smith, H. N. (1959). Can 'American studies' develop a method? American Quarterly, 9(2), 197-208.

Tate, C. F. (1973). The search for a method in american studies. Minneapolis: University of Minnesota Press.

Vanderstraeten, R. (2010). Scientific communication: sociology journals and publication practices. Sociology, 44(3), 559-576.

Welter, B. (1966). The cult of true womanhood: 1820-1860. American Quarterly, 18(2), 151-174.

Williams, J. E., \& MacLean, V. M. (2005). Studying ourselves: sociology discipline-building in the United States. American Sociologist, 36(1), 111-113.

Wise, G. (1979). 'Paradigm dramas' in american studies: a cultural and institutional history of the movement. American Quarterly, 31(3), 293-337. 